\title{
Influence of Strategy Execution on Academic Performance of National Schools in Kenya
}

\author{
Clare Gakenia $^{1}$, Prof. Paul Katuse ${ }^{2}, \&$ Dr.Peter Kiriri ${ }^{3}$ \\ ${ }^{1}$ Corresponding Author and Doctorate Student at United States International University, Africa \\ ${ }^{2,3}$ Lecturers at United States International University, Africa
}

\begin{abstract}
The role of leadership in a school is of importance to the academic performance of the school which is its core mandate. The school principal or head teacher is the head of the school and performs critical functions that dictate on the academic performance of the school. The school principals are charged with five major roles including administering the approved school curriculum, school finance and business, staff and students in the school, school plant and equipment and school community relations. The principal as the chief executive is the overall in charge of the school and is responsible for the quality of the school. S/he supervises the whole school programs and bears the ultimate responsibility for the overall school performance, proficiency and effectiveness including the competency of all school programs. The head is the secretary to the BOG, and in charge of the day-to-day activities in the school. He should understand the departmental programs and work closely with all the teachers through consultation on issues of mutual interest to the school like games and sports, other co-curricular activities and examinations. The school head should be well informed and experienced on the school system and should have an orientation to the whole school program. The school principals play the role of administrators in addition to teaching duties that they may have. In this capacity, the school principals coordinate the efforts of diverse stakeholders towards the achievement of the school educational goals. These stakeholders include the teachers, parents, students, education officials and the community surrounding the school. These stakeholders influence the academic goals of the institution in diverse ways. Amongst the stakeholder management functions or coordinating efforts that the principals undertake include professional advice to the school board, leaders of reforms, managers of resources and communicators to the public. School leadership is therefore concerned with pupils, teachers and the rules, regulations and policies that govern the school system. This study sought to examine the role of strategy execution on the performance of national schools. The cumulative effect of strategy execution metrics on the academic performance was examined using multiple linear regression analysis. The positive multiple correlation coefficient $(R)$ indicated the cumulative effect of strategy execution is positively correlated to academic performance of national schools. There is a strong and positive correlation of 0.479 between the strategy execution and academic performance of national schools. On the other hand, the coefficient of determination $(R$ Square) of 0.229 indicates that $22.9 \%$ of the variance in academic performance can be attributed to strategy execution in national schools.To examine if the multiple linear regression was a good fit for data, then the ANOVA of strategy Execution was examined. Since $F(11,75)=2.030, p<0.037$ then the model was considered a good predictor of academic performance as a p value of 0.037, implied only a $3.7 \%$ likelihood of a multiple linear regression model giving the wrong responses. Therefore, the multiple linear regression of strategy execution was undertaken.
\end{abstract}

Keywords: Academic Performance, Strategy Execution

\section{Introduction}

The strategy execution relates to the use of managerial and organizational tools to direct resources towards the achievement of strategic results. The strategy execution has also been defined as the administration and execution of strategy plan. The strategy execution has also been defined as the building of capable organization through resources allocation to critical action plans, establishment on an enabling environment, embracing best practices as well as best practices. Strategy execution has also been depicted as when the strategy gets relayed to the organization, so that the staff involved knows the "what", "why" and "how" of the strategy ( (Wit \& Meyer, 2010)). It is where the people, departments, budgets and resources involved are allocated and coordinated in a cooperating symbiosis. Strategy execution is also considered to be the moderation through which the actual implementation processes is scrutinized, managed and adjusted to the experiences and consequences that the organization encounter, as a result of implementing the strategy (Pedersen, 2008). Macharia (2011) indicates that strategy implementation involves the resources allocation in the pursuing of the chosen strategies within an organization. According to Karani, (2009), strategy has been defined as the direction and scope the organization wishes to go in the long-term. "Strategy has also been defined as a set of decisions that guides organizations' operations. Strategy execution is the practice of 
translating, communicating, coordinating, adapting and allocating resources to a chosen strategy; while managing the process of strategy implementation" (Pedersen, 2008).

Strategy execution is a critical influencer of performance in any organization. There are diverse factors that influence strategy implementation and its success including top management commitment, employee engagement, communication of strategies, cascading accountabilities, selecting the best people to drive key initiatives, and the ability to monitor and tract progress. Other aspects include adequacy of feedback system, sufficiency of resources, resources deployment, leadership skills, staff motivation, and a supportive company culture. Yet knowing this, from the core, Chris Zook and James Allen in their book seven out of every eight companies in the global study from 1988 to 1998 of 1854 large corporates failed to achieve their targeted growth by $5.5 \%$ in revenues and earnings, while earning their cost of capital. Yet this companies had developed detailed strategic plans (Kaplan \& Norton, 2005).

Strategy execution is been an aspect that has been widely ignored in the book literature and even in the university courses. Much more attention is paid to strategy formulation yet even with the perfect strategy and the wrong formulation, the result is unachieved goals (Pedersen, 2008). Though there are many variation to this process the ideal remains the same, according to (Wit \& Meyer, 2010) most textbooks have portrayed the strategy process as a basic linear progress through a number of steps which are mainly analysis stage, formulation and lastly the implementation stage. The implementation stage is where the top managers hand over the formulated strategy to the sublevel managers for implementation without structured thought through process. Strategy execution continues to be an enigma that has not been explored extensively in the literature over the years. Hrebiniak (2005) details that management literature has often focused on primarily parading the new ideas of planning and strategy formulation however they have sorely neglected execution.

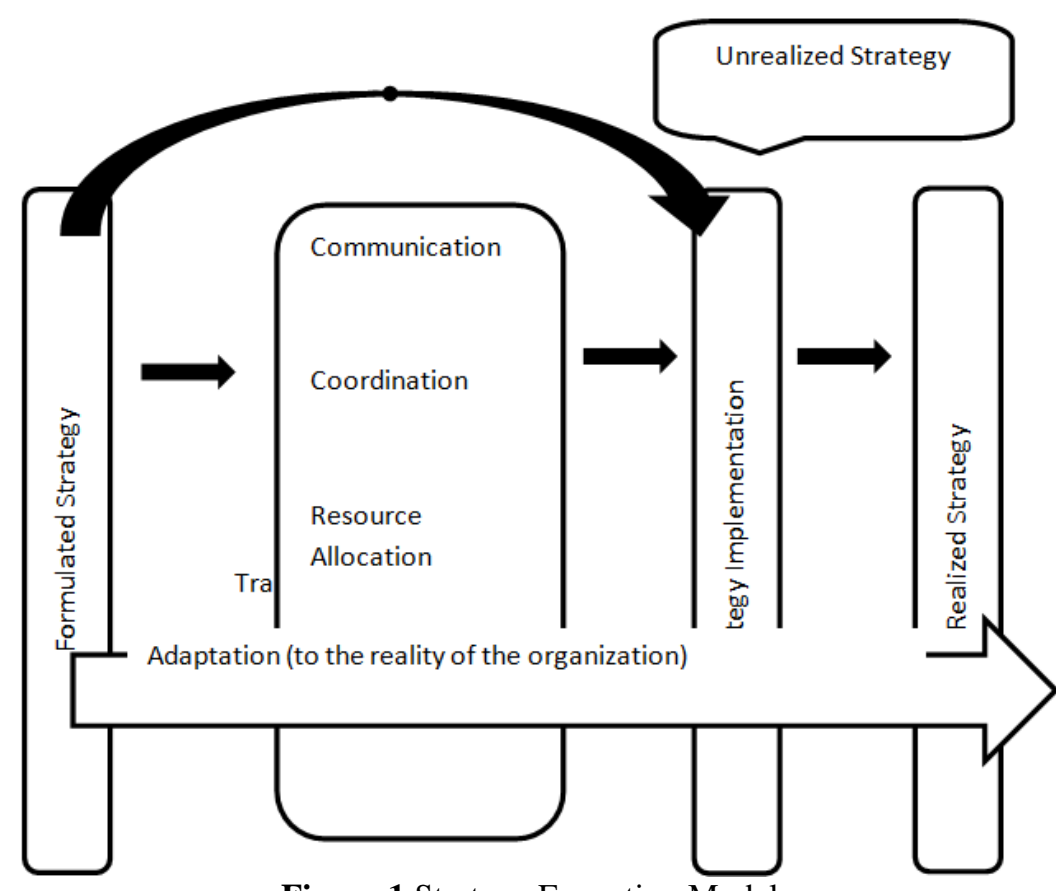

Figure 1 Strategy Execution Model

The strategy execution model (SEM) illustrates how the elements of strategy execution converge the strategy plan to a tangible outcome. The execution process has two key elements; adequate translation of strategy and adaptation to reality. In pertinence to strategy execution in schools, similarly to the other economic sectors there is need of use of human, material and financial resources for functionality of the institution. (Wanjala \& Rarieya, 2014). Strategic planning has been identified as a valuable framework for effective implementation of school reforms and empowers schools to effectively respond to their needs (Fullan, 2004;Gamage, 2006; Steyn \& Wolhunter, 2010). Strategic planning has been advocated as a tool for change management to lead school reforms and change the way people work (Fullan 2004). Strategic planning and implementation provides an inclusive way for school planning, which critical for soliciting higher commitment to the implementation of change (Fullan 2004). Hence, it has the potential to enhance collaborative and collegial working relationships among school community members (Wanjala \& Rarieya, 2014). Research by Wanjala (2014) depicted that Kenyan secondary schools have a long way to go in the full integration of comprehensive strategies. Most of the strategies are mainly in the leaders mind and with the prevalent hierarchical and 
bureaucratic leadership impacts planning process within the schools this is because central line-management and defined positions of power inhibit the strategic planning processes that call for a level and relationship-driven leadership which purposes to develop schools as more fluid organisations (Davies \& Davies 2010). It is however notable that schools that have strategies in place and appropriately executed have a significant impact on the performance (Bell, 2002). With this in perspective in this study it will be important to also appreciate the impact of strategy execution

\section{Literature Review}

Strategic implementation and alignment is the most important yet the most difficult part of strategic leadership (Brecken, 2004). According to David \& David (2004) Kaplan and Norton (2001) argue that strategy can be translated into action through the use of 'strategy maps' and 'balanced scorecards' as they 'provide a framework to describe and communicate strategy in a consistent and insightful way'. Execution of strategy entails the transformation of the current frame of mind of the institution. When executing change / translating the culture of the organization; there are two principal aspects that have to change; the culture - the mindset and the behavior of the people within the organization. Wilson (1997) states 'organizational change has two principal aspects; change in mission and strategy and change in culture and behavior" to ensure alignment.

According to Tichy and Sharman (1993) there is a three stage process to transform the strategy into action; Firstly there is the awakening stage; it involves building an agreement within the school that a continuation of the current way of working will not deliver the effectiveness desired in the future. Secondly is the envisioning stage. This entails the creation of a clear picture of what the new way of operating looks like and creation of the capacity to achieve it. Finally there is the new architecture of the new institution or in this case a school then emerges. It is important to remember that strategy is a neutral delivery vehicle. If you have a poor vision and a dubious moral purpose then a good strategic process and approach may effectively deliver it for you (Davies, 2015). This means that the strategy's existence is not in a vacuum environment it requires be part of a wider process of values-led leadership and futures visioning.

Alignment in an organization suggest that there is strong connnection between the employees activities, organization structures and product offering. Chorn (1991); Labovitz \& Rosansky (1997), stated that the strength of the alignment theory is its ability to pool the organization members into a more logical and cohesive structure. They concurred that the alignment is essential because it "provides a way for capturing the best approaches by linking strategy and people and integrating them with customers and process improvement". The strategic leader in the schools- the principal has the role to align the staff. The principal should govern the strategic conversation and dialogue relating to the issues and concerns facing school and the future outlook of the school. These conversations enable people to develop a strategic perspective of what the school might become. Further engagements in discussions evokes staff participation which leads to greater participation and increase in understanding. The process of greater awareness and participation in discussion is a key way which develops alignment. This is because the leader aligns by motivating individuals in the organization as they develop a strategic cause in which individuals contribute leading to increased commitment and effort.

Gratton (2000) advocates developing 'emotional capabilities, trust-building capabilities and capabilities to build a 'psychological contract' as the means of engaging and motivating staff. When people are involved and part of something they believe in they are better able to identify with the short and long-term goals of the strategy. Building commitment to values and long-term ambitions provides individuals with a vision and sense of direction that allows them to put short term problems and challenges into context (Davies \& Davies, 2004). Davies (2005) suggests a four-stage ABCD approach of translating strategy into action as detailed below;

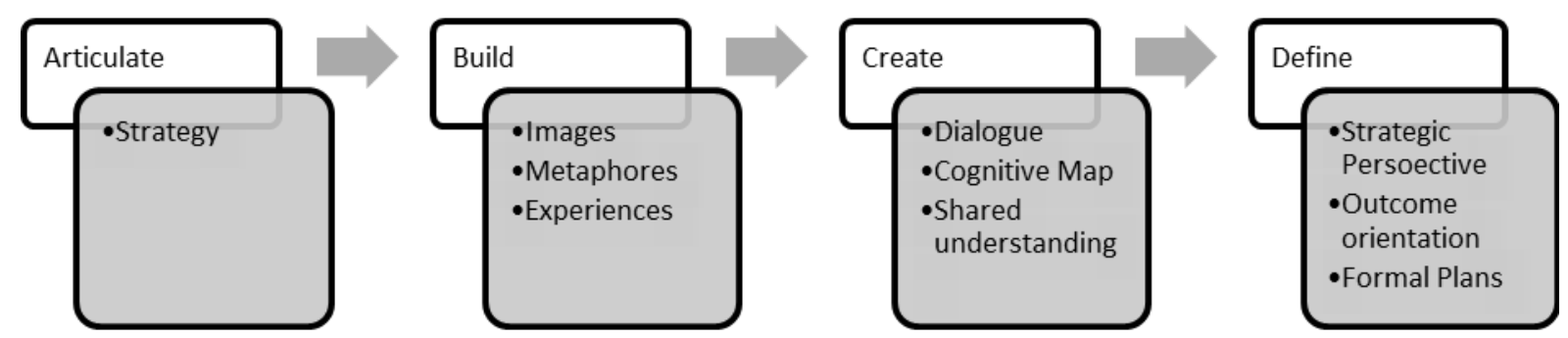

Figure 2 The ABCD Approach 
According to Davies and Davies (2006) there is a four stage approach toward translating the strategy into action written and structural. Oral articulation is the way leaders communicate, through strategic conversations, the strategic purpose and direction of the organization. Written articulations refer to the formal statements and plans that are clearly distinguishable from operational short-term plans. Structural articulation refers to the organizational infrastructure that supports and develops the strategic approach.

Second, in building common understanding of what is possible through shared experiences and images; the building stage entails envisioning a clear and understandable picture of what this new way of operating would look like. This involves awakening the people in the school to alternative perspectives and experiences, and building an agreement within the school that a continuation of the current way of working is inadequate if the school wants to be effective in the future (Davies, 2005)

Third, the leadership needs to create through dialogue a shared conceptual or mental map of the future. What strategic leaders are able to do is step back and articulate the main features of the current organization, which might be called the strategic architecture (Kaplan and Norton, 1996; 2001) of the school, and lead others to define what the future of the school and the new architecture will be. This may involve the process, described by Davies (2003), of enhancing participation and motivation to understand the necessity for change, through strategic conversations. Significantly it draws on high-quality information both from within and outside the organization which is part of the strategic analysis that underpins the dialogue. Fourth, the leadership needs to define desired outcomes and the stages of achieving those outcomes. This will establish a clear picture of the new strategic architecture of the school. Tichy and Sharman (1993) identify this stage as involving the identification of a series of projects that need to be undertaken to move the organization from its current to its future state.

Additionally in creating alignment within the organization the leader should building capability within this organization. This is achieved through the strategic conversation and enhanced participation building greater personal and organizational capability and capacity (Davies, 2005). Given that the major resource of any organization is the quality of its human capital, then enhancing that quality should be a major organizational focus. It is useful to differentiate between capability and capacity. Capacity can be considered the resource level that is available at any given moment to achieve an objective. Capability is that mix of skills and competencies possessed by the people in the organization which is needed to achieve the task. The right number of people may not, at a particular juncture, have the right skills. However, when they do, it can be said that both capacity and capability are present. Boisot, (2003) states that, 'we shall use the term capability to depict a strategic skill in the application and integration of competencies'. This idea was seen by a school leader as: 'the ability to work at challenges together to bring skills of other people to bear so the organization can learn to solve problems and not just rely on simplistic external solutions' (Davies \& Davies, 2006).

The leadership challenge of when to make a significant strategic change is as critical to success as choosing what strategic change to make. The issue of timing can rest on leadership intuition (Parikh, 1994) as much as on rational analysis. When individuals in the organization are ready for change, when the organization needs the change and when the external constraints and conditions force the change, all have to be balanced one against the other. Such judgment is manifested in not only knowing what and knowing how but also knowing when (Boal \& Hooijberg, 2001)as important, knowing what not to do (Kaplan \& Norton, 2001). Therefore we could add to this list knowing what to give up or abandon in order to create capacity to undertake the new activity. Several of the school leaders in the study highlighted the essence of strategic timing, in ensuring they get it right not just for themselves but also for the institution. They observed that the timing was more of an intuitive aspect (Davies, 2005). If the strategic timing is wrong it can have devastating effects on the school. People will be divided, and realizing the strategy will therefore be impossible. In addition to the critical skill of strategic timing is that of strategic abandonment. If a school adopts a new way of doing things or adopts a new strategic priority, how that fits into an already crowded agenda has to be considered. Sometimes these strategies have been abandoned as they did not tie into the current impacting factors. This may result in the institution abandoning the current strategy for the more likely one which will be in tune with the emerging concerns.

Strategic capability can be defined as the resources and competences of an organization need to survive and prosper. Prahalad \& Hamel (1990) use the term 'core competencies' whileStalk, Evans, \& Schulman (1992) use the term 'strategic capabilities'. Davies \& Davies (2006) The strategic capabilities are divided into two categories; threshold capabilities and capabilities for competitive advantage which are comprised of unique resources and core competencies, both difficult to imitate for competitors Johnson, Scholes and Whittington., (2009) identify strategic capabilities are those resources and competences capabilities needed by an organization to meet minimum customer requirements and for it survival or they could be the threshold competences required to deploy resources so as to meet customers' requirements and support particular strategies. To survive and prosper an organization needs to understand the challenges of the environment that it faces. It should be clear the capable of delivering in terms of the critical success factors that arise from demands and needs of its customers. The strategic capability to do so is dependent on the resources and the competences it has. These 
must reach a threshold level in order for the organization to survive. Additionally the organization should be capable of achieving competitive advantage, this requires it to have strategic capabilities that its competitors find difficult to imitate or obtain, it could be in form of a resource or core competences of the organization (The strategic position: strategic capabilities, 2007). Strategic leaders display a sense of dissatisfaction or restlessness with the present status or situation. This restlessness involves living the reality of having to manage the current situation and not being able to change it for some time until greater capacity and capability has been built (Ercetin \& Maya, 2010). This restlessness is also termed as creating tension by Senge (1999) emerging from a seeing the disparity between the vision and the reality of the way things are. Strategic leaders are able to envision the 'strategic leap' that an organization wants to make, while acting as passionate advocates for change (Davies \& Davies, 2004).

Strategic leaders also have absorptive capacity which is the ability for an organization to teach (Evans \& Lindsay, 2008). According to Cohen and Levinthal (1990), absorptive capacity is the capacity to recognize new information, assimilate it and apply it toward productive ends. Boal and Hooijberg (2001, p. 517) also call this 'absorptive capacity' and argue that leaders 'have a unique ability to change or reinforce existing action patterns' within the organization. It is thus clear that a strategic leader needs to have the ability to identify, understand and assimilate new information that is beneficial to the organization's growth. The critical nature of their position often means their interpretation of reality determines patterns of action within the organization (Davies \& Davies, 2004).

Strategic leaders have adaptive capacity which is the ability to change and learn in response to the institution/ organization needs. Davies (2004) firms up that in this era of innovation and continuous learning where success may depend on a flexible strategic response, it is important to have the strategic absorptive capacity and it may favor emergent strategy or strategic intent approach. Leaders require the ability to learn and change according to Sanders (1998), they need to adapt through the chaos and adapt new ways of thinking and seeing. Strategic leaders have strategic wisdom. According to Robert Stenberg successful intelligence is achieved where there is a combination of practical intelligence, analytical intelligence and emotional intelligence. Additionally Boal and Hoojberg (2001) observed that most researchers intimate that leaders need to have important interpersonal skills such as empathy, motivation and communication. A broad list has been itemized by Robert in addressing the nature of wisdom in a strategic leader; successful intelligence, balancing of interests, balancing of timeframes, mindful infusion of values, balancing of responses to the environment , application of knowledge for the common good. Bennet (2000) also adds to the list by including integrity, social justice, humanity, respect, loyalty and a sharp distinction between right and wrong. Gardner (1985) espouses the need for a strategic leader to have social intelligence as the ability to notice and make distinction among other individuals particularly in relation to their moods, temperament, motivation and intentions.

Becoming aligned does not simply happen. Someone in a position of power has to make it happen with a huge push or some type of Herculean effort (Labovitz \& Rosansky, 1997). Real change almost always starts at the top. To achieve the vision, the organization needs to produce results through the existing processes in the organization, and the creation of new processes to deliver additional results (Khadem, 2008: 34). According to Labovitz and Rosansky (1997), a hierarchy that stresses command and control can claim to do neither. Measurements tied to company objectives are the key to vertical alignment. The importance that the Top level management attributes to determining the organization's strategic direction must be matched with the communication and deployment of the strategy throughout the organization. Involving employees in the process of strategy determination will result in faster more effective deployment (Lear 2012). Alignment is essential and produces dramatic benefits for organizations (Kaplan \& Norton, 2006), and alignment is critical if organizations are to achieve synergies through their business and support units (Kaplan \& Norton, 2006). While the necessity for an alignment between the organization's strategies, customers, processes and people is theoretically founded, only a few researchers have empirically studied the nature of alignment and its influence on the learning institution's performance. Alignment of the four constructs of strategic leadership, strategy, customers, processes and people, falls within the context of the current research.

Strategic alignment can be defined as a Partnership, which is used to describe a working relationship reflecting a long-term commitment, a sense of mutual cooperation, shared risk and benefits, and other qualities consistent with concept and theories of participatory decision making (Handerson, 1990).It is the link between an organization's overall goals and the goals of each of the units that contribute to the success of those overall goals (Andolsen, 2007). Alignment in an organization can be termed as arrangement within the organization that ensures the set goals for which the organization is functioning are met. Alignment in an organization suggest that there is strong connnection between the employees activities, organization structures and product offering. Chorn (1991) and Labovitz and Rosansky (1997) stated that the strength of the alignment theory is its ability to pool the organization members into a more logical and cohesive structure. They concurred that the alignment is essential because it "provides a way for capturing the best approaches by linking strategy and people and integrating them with customers and process improvement" (p. 13). The principle of Strategic "fit" which is the 
degree of alignment that exist between competitive situation, strategy, organization culture and leadership has been largely attributed to the superior performance of organizations (Chorn, 1991).

Strategic alignment is a state in which the strategic goals are guiding the employees, customers and key processes to work in unison to achieve the goals set for the organization. Aligned organizations enjoy greater customer and employee satisfaction and produce superior returns for shareholders Labovitz (2004); maintains that alignment gives managers at every level of the organization the ability to rapidly deploy a coherent business strategy, be totally customer focused, develop world-class people and continuously improve business processes - all at the same time. Strategic alignment furthermore provides a means to measure the effectiveness of organizations. Khadem (2008) stipulates that when two people are aligned when they move in the same direction. They are integrated when they cooperate with each other. Thus total alignment encompasses both alignment and integration. It is possible to be aligned but not integrated. This is evident when two people move in the same direction but without cooperation. Khadem (2008) maintains that alignment needs a center of focus or frame of reference for all employees, which is the vision, values and strategy of the organization. Alignment therefore means cooperation and integration with the organization's vision, values and strategy. Hence, according to Khadem (2008), the most effective way to make an organization's business strategy effective is through alignment and follow-up. This means that in an organization where there is a state of alignment, the employees understand their contribution toward to the strategy objectives and strives to make a contribution to its realization.

The role of leadership in a school is of importance to the academic performance of the school which is its core mandate. The school principal or head teacher is the head of the school and performs critical functions that dictate on the academic performance of the school. The school principals are charged with five major roles including administering the approved school curriculum, school finance and business, staff and students in the school, school plant and equipment and school community relations. The principal as the chief executive is the overall in charge of the school and is responsible for the quality of the school. S/he supervises the whole school programs and bears the ultimate responsibility for the overall school performance, proficiency and effectiveness including the competency of all school programs. The head is the secretary to the BOG, and in charge of the day-to-day activities in the school. He should understand the departmental programs and work closely with all the teachers through consultation on issues of mutual interest to the school like games and sports, other cocurricular activities and examinations. The school head should be well informed and experienced on the school system and should have an orientation to the whole school program

The school principals play the role of administrators in addition to teaching duties that they may have. In this capacity, the school principals coordinate the efforts of diverse stakeholders towards the achievement of the school educational goals. These stakeholders include the teachers, parents, students, education officials and the community surrounding the school. These stakeholders influence the academic goals of the institution in diverse ways. Amongst the stakeholder management functions or coordinating efforts that the principals undertake include professional advice to the school board, leaders of reforms, managers of resources and communicators to the public. School leadership is therefore concerned with pupils, teachers and the rules, regulations and policies that govern the school system. The school leadership also plays a critical role in creating a conducive environment for learning and teaching activities to take place. In this context, the school leaders promote a shared vision, mobilizes the stakeholders, lead curriculum and pedagogical practice, administrate effectively and reflect critically on all practice in the institution. The school leadership also involves the inspiring and supporting others towards the achievement of the school vision which is based on clear personal and professional value. Essential functions of school leadership involve traditional competencies of integration, coordination, assimilation of details, capacity for multi-perspectives, diplomacy and corebusiness competency. School principals therefore have to embrace the best practices to be effective and efficient by creating and sustaining a competitive school. Principals have to develop and implement strategic school improvement plans and provide instructional guidance to improve learning. The school leadership also cultivates and facilitates professional growth of teachers through planned educational seminars, conferences and in-service education programs teachers can improve immensely on their performance. The school leadership also formulates policies and practices that aid in the academic performance of the institution. This is achieved through decision making in aspects such as school rules, regulations and programs. These aspects are facilitated through staff meetings, students' council, clubs, committees and organizations involved in running the school.

The success of any school is dependent on its leadership. The schools which fail have weak leadership such as failure to sell its vision to its followers; the inability to respond or identify threats; overestimating their ability to control the school's external environment; having no boundary between their interests and those of the school; eliminating all those who disagree with them; and underestimating obstacles and relying on what worked in the past. The strategy execution relates to the use of managerial and organizational tools to direct resources towards the achievement of strategic results. The strategy execution has also been defined as the administration and execution of strategy plan. The strategy execution has also been defined as the building of 
capable organization through resources allocation to critical action plans, establishment on an enabling environment, embracing best practices as well as best practices. Macharia (2011) indicates that strategy implementation involves the resources allocation in the pursuing of the chosen strategies within an organization. According to Karani, (2009), strategy has been defined as the direction and scope the organization wishes to go in the long-term. Strategy has also been defined as a set of decisions that guides organizations' operations.

Strategy execution is a critical influencer of performance in any organization. There are diverse factors that influence strategy implementation and its success including top management commitment, employee engagement, communication of strategies, cascading accountabilities, selecting the best people to drive key initiatives, and the ability to monitor and tract progress. Other aspects include adequacy of feedback system, sufficiency of resources, resources deployment, leadership skills, staff motivation, and a supportive company culture. The human resources factors play a critical role in strategy execution within the context of performance in any institutions. The human resource factors in strategy execution includes diverse aspects such as recruitment, selection, training, transfers, promotions and lay off of employees with a view of attaining strategic goals. The success of the strategy execution occurs with the identification of the right staff in the critical positions within the organization. The right people relates to their skills, education qualification, track records, values, and management styles amongst other aspects. The organizational structure affects the strategy execution within an institution. In this context, Karani (2009) notes that organizational structure is the ideological glue that holds the organization together enabling the organization's ability to pursue strategy. This is because organizational structure determines the employees' behaviors. The value creation activities of organization members are meaningless unless some type of structure is used to assign people to tasks and connect the activities of different people and functions.

The strategy execution relates to embracing change in the way of doing things in an organization in order to achieve certain objectives in a faster and more efficient ways. In this context, leadership plays a critical role in the strategy implementation as the leaders are the owners of change. The leadership has been described as the most significant force that enables the success or failure of strategy execution. The leadership also create conducive environment for the strategy execution through creation of policies, organizational structures, and organizational procedures. Kinyanjui (2015) examined the relationship between strategic leadership and strategy execution. The study notes that there are several attributes that strategic leaders have that influence strategy execution including determination of strategic direction, establishing balanced organizational controls, effective managing the organization's resource portfolio and sustaining an effective organizational culture. Strategic leadership provides the scope and direction to help drive success for the organization. The strategic leader is able to influence the change management, staff motivation, and team work amongst the employees.

\section{Objective of the Study}

To determine the impact of a strategic leader's strategy execution primarily implementation and alignment on the academic performance of the National schools in Kenya.

\section{Methodology}

The study used descriptive research design. A population is the complete group of entities that will be examined in the study (Zikmunnd, Babin, Carr, \& Griffin, 2013). The target population is examined using the units of observation and units of analysis. The unit of observation refers to the units in which the information is received and statistics are compiled or an object about which information is collected (Cooper \& Schindler, 2003). The unit of observation has also been defined as the identifiable organizations or physical entities which are able to report data about their activities (Mugenda, 2003). The unit of observation for this study was the national secondary schools deputies or department heads in Kenya in the 103 national schools. According to the Ministry of Education (2017), there are 103 national schools within the country. The total number of students in these national schools is approximately 107388. The national schools are represented in every county thus the information gathered would be representing the country. To ensure that the results acquired were not influenced by aspects of differentiation of the schools in entities such as cognitive ability of the students, infrastructure, government funding a choice to use institutions that are somewhat at par in resources was reached. This ensured that neither of the schools had an added advantage in relation to resources. The sample size of this study was 93 principals of national secondary schools that were drawn using census sampling. Therefore, 93 questionnaires were distributed to the respondents of which only 87 questionnaires were returned making a response rate of $93 \%$. The six unreturned questionnaires were attributed to unwillingness amongst some principals to participate in the study. This is despite the issuance of a consent letter indicating that (i) the study is meant for an academic purpose only, (ii) maintenance of anonymity in their responses, and (iii) promise of keeping their information confidential. This response rate was deemed sufficient for study. This is because Sekaran \& Bougie, (2011) indicates that a response rate of over $85 \%$ being excellent, $70-85 \%$ very good, $60-70 \%$ acceptable and below $50 \%$ not acceptable. 


\section{Findings And Discussions \\ Frequency Distribution of Strategy Execution}

The aspect of the national school continuously assessing progress relative to these action plans is critical as indicated by $43.7 \%$ and $56.3 \%$ of the respondents who agreed and strongly agreed to the metric respectively. This is in line with Bass (2007) findings that Strategic leaders make and communicate decisions for their organizations' future. They formulate the organizations' goals and strategies; develop structures, processes, controls and core competencies for the organization; manage multiple constituencies; choose key executives; groom the next generation of executives provide direction with respect to organizational strategies: maintain an effective organizational culture; sustain a system of ethical values; and serve as the constituencies, as well as negotiate with them (Bass, 2007: 36). A cumulative percentage of $100 \%$ of the respondents were affirmative that they compare notes with their competing schools and key benchmarks. A majority of $56.3 \%$ of the respondents strongly agree that their respective schools collect and integrate information about student learning. A majority of $71.3 \%$ of the respondents indicated that their faculty promotion process was based on accepted principles of academic performance.

On the other hand, in relations to national schools having effective ways of motivating faculty and staff to develop and utilize their full potential, $14.9 \%$ and $85.1 \%$ of the respondents indicated that they agreed and strongly agreed respectively. The staff alignment and motivation is of critical importance to performance. Alignment in an organization suggests that there is strong connection between the employee's activities, organization structures and product offering. Chorn, 1991; Labovitz \& Rosansky, 1997 stated that the strength of the alignment theory is its ability to pool the organization members into a more logical and cohesive structure. They concurred that the alignment is essential because it "provides a way for capturing the best approaches by linking strategy and people and integrating them with customers and process improvement".

Table 1: Frequency Distribution of Strategy Execution

\begin{tabular}{|c|c|c|c|c|c|}
\hline & SD & D & $\mathbf{N}$ & $\mathbf{A}$ & $\mathbf{S A}$ \\
\hline & Freq. & Freq. & Freq. & Freq. & Freq. \\
\hline & $(\%)$ & $(\%)$ & $(\%)$ & $(\%)$ & $(\%)$ \\
\hline \multirow{2}{*}{$\begin{array}{l}\text { We continuously assess progress relative to these action } \\
\text { plans }\end{array}$} & 0 & 0 & 0 & 38 & 49 \\
\hline & $0.00 \%$ & $0.00 \%$ & $0.00 \%$ & $43.70 \%$ & $56.30 \%$ \\
\hline \multirow{2}{*}{$\begin{array}{l}\text { We compare our projected performance with the } \\
\text { projected performance of competitors and key } \\
\text { benchmarks }\end{array}$} & 0 & 0 & 0 & 25 & 62 \\
\hline & $0.00 \%$ & $0.00 \%$ & $0.00 \%$ & $28.70 \%$ & $71.30 \%$ \\
\hline \multirow{2}{*}{$\begin{array}{l}\text { We collect and integrate information on evidence of } \\
\text { student learning }\end{array}$} & 0 & 0 & 0 & 38 & 49 \\
\hline & $0.00 \%$ & $0.00 \%$ & $0.00 \%$ & $43.70 \%$ & $56.30 \%$ \\
\hline \multirow{2}{*}{$\begin{array}{l}\text { Our faculty promotion process is based on accepted } \\
\text { principles of academic performance }\end{array}$} & 0 & 0 & 0 & 25 & 62 \\
\hline & $0.00 \%$ & $0.00 \%$ & $0.00 \%$ & $28.70 \%$ & $71.30 \%$ \\
\hline \multirow{2}{*}{$\begin{array}{l}\text { We have effective ways in motivating faculty and staff } \\
\text { to develop and utilize their full potential }\end{array}$} & 0 & 0 & 0 & 13 & 74 \\
\hline & $0.00 \%$ & $0.00 \%$ & $0.00 \%$ & $14.90 \%$ & $85.10 \%$ \\
\hline \multirow{2}{*}{$\begin{array}{l}\text { We have effective ways in determining and ensuring } \\
\text { our LCP }\end{array}$} & 0 & 0 & 4 & 36 & 47 \\
\hline & $0.00 \%$ & $0.00 \%$ & $4.60 \%$ & $41.40 \%$ & $54 \%$ \\
\hline \multirow{2}{*}{$\begin{array}{l}\text { Our LCP address student educational and } \\
\text { developmental needs to maximize their success }\end{array}$} & 0 & 0 & 1 & 39 & 47 \\
\hline & $0.00 \%$ & $0.00 \%$ & $1.10 \%$ & $44.80 \%$ & $54 \%$ \\
\hline \multirow{2}{*}{$\begin{array}{l}\text { We incorporate inputs from students, faculty, staff and } \\
\text { stakeholders to determine key LCP requirements }\end{array}$} & 0 & 0 & 2 & 30 & 55 \\
\hline & $0.00 \%$ & $0.00 \%$ & $2.30 \%$ & $34.50 \%$ & $63.20 \%$ \\
\hline \multirow{2}{*}{$\begin{array}{l}\text { We continuously improve our LCP to maximize student } \\
\text { success and improve educational programs }\end{array}$} & 0 & 0 & 1 & 24 & 62 \\
\hline & $0.00 \%$ & $0.00 \%$ & $1.10 \%$ & $27.60 \%$ & $71.30 \%$ \\
\hline \multirow{2}{*}{$\begin{array}{l}\text { We have effective ways in determining and ensuring } \\
\text { our key SP's }\end{array}$} & 0 & 0 & 1 & 31 & 55 \\
\hline & $0.00 \%$ & $0.00 \%$ & $1.10 \%$ & $35.60 \%$ & $63.20 \%$ \\
\hline \multirow{2}{*}{$\begin{array}{l}\text { We incorporate inputs from students, faculty, staff and } \\
\text { stakeholders to determine key SP requirements }\end{array}$} & 0 & 0 & 26 & 59 & 2 \\
\hline & $0.00 \%$ & $0.00 \%$ & $29.9 \%$ & $67.80 \%$ & $2.30 \%$ \\
\hline
\end{tabular}

The strategic leader in the schools- the principal has the role to align the staff. The principal should govern the strategic conversation and dialogue relating to the issues and concerns facing school and the future outlook of the school. These conversations enable people to develop a strategic perspective of what the school might become. Further engagements in discussions evokes staff participation which leads to greater participation and increase in understanding. The processor greater awareness and participation in discussion is a key way which develops alignment. This is because the leader aligns by motivating individuals in the organization as they develop a strategic cause in which individuals contribute leading to increased commitment and effort. Gratton (2000) advocates developing 'emotional capabilities, trust-building capabilities and capabilities to build a 'psychological contract' as the means of engaging and motivating staff. When people are involved and part of something they believe in they are better able to identify with the short and long-term goals of the strategy. Building commitment to values and long-term ambitions provides individuals with a vision and sense of direction that allows them to put short term problems and challenges into context (Davies \& Davies, 2004). In respect to national schools having effective ways of determining and ensuring their LCP, $4.6 \%$, 
$41.4 \%$, and $54 \%$ of the respondents were neutral, disagreed and strongly disagreed respectively. On the current LCP addressing students' educational and developmental needs to maximize on their success, a majority of $54 \%$ of the respondents strongly agreed to the metric. A cumulative percentage of 70.1 were affirmative that the national school incorporated inputs from students, faculty, staff and stakeholders to determine key SP requirements.

\section{Means and Standard Deviations of Strategy Execution}

The means and the standard deviations of strategy execution were examined using a five point likert scale with descriptors Strongly Disagree (SD), Disagree (D), Uncertain (U), Agree (A) and Strongly Agree (SA). These were represented as 1,2,3,4 and 5 respectively in the SPSS input spread sheet. The interpretation of the scores $1<\mu<1.5,1.5<\mu<2.5,2.5<\mu<3.5,3.5<\mu<4.5$, and $4.5<\mu \leq 5$ where $\mu$ represents the mean were that the respondents on average tended to strongly disagree, disagree, be uncertain, agree and strongly agree respectively in relations to the given metric.

Table 2: Means and Standard Deviations of Strategy Execution

\begin{tabular}{|c|c|c|c|c|c|}
\hline & \multirow[t]{2}{*}{$\mathbf{N}$} & \multicolumn{2}{|c|}{ Mean Calculations } & \multicolumn{2}{|c|}{ Std. Dev. Calculations } \\
\hline & & Mean & $\begin{array}{l}\text { Respondents } \\
\text { on average } \\
\text { tended to; }\end{array}$ & $\begin{array}{l}\text { Std. } \\
\text { Dev. }\end{array}$ & $\begin{array}{c}\text { Responses } \\
\text { Distributed } \\
\text { around the mean; }\end{array}$ \\
\hline $\begin{array}{l}\text { We compare our projected performance with the projected } \\
\text { performance of competitors and key benchmarks }\end{array}$ & 87 & 4.7586 & $\begin{array}{l}\text { Strongly } \\
\text { Agree }\end{array}$ & 0.4304 & Closely \\
\hline $\begin{array}{l}\text { Our faculty promotion process is based on accepted principles } \\
\text { of academic performance }\end{array}$ & 87 & 4.7126 & $\begin{array}{l}\text { Strongly } \\
\text { Agree }\end{array}$ & 0.45515 & Closely \\
\hline $\begin{array}{l}\text { We have effective ways in motivating faculty and staff to } \\
\text { develop and utilize their full potential }\end{array}$ & 87 & 4.8506 & $\begin{array}{l}\text { Strongly } \\
\text { Agree }\end{array}$ & 0.35857 & Closely \\
\hline We have effective ways in determining and ensuring our LCP & 87 & 4.4943 & Agree & 0.58813 & Moderately \\
\hline $\begin{array}{l}\text { We continuously improve our LCP to maximize student } \\
\text { success and improve educational programs }\end{array}$ & 87 & 4.7011 & $\begin{array}{l}\text { Strongly } \\
\text { Agree }\end{array}$ & 0.48501 & Closely \\
\hline $\begin{array}{l}\text { We have effective ways in determining and ensuring our key } \\
\text { SP's }\end{array}$ & 87 & 4.6207 & $\begin{array}{l}\text { Strongly } \\
\text { Agree }\end{array}$ & 0.5113 & Moderately \\
\hline $\begin{array}{l}\text { We incorporate inputs from students, faculty, staff and } \\
\text { stakeholders to determine key SP requirements }\end{array}$ & 87 & 4.7241 & $\begin{array}{l}\text { Strongly } \\
\text { Agree }\end{array}$ & 0.49859 & Closely \\
\hline
\end{tabular}

On the other hand, the standard deviation interpretation with the scores $0<\sigma \mathrm{X}<0.5,0.5<\sigma \mathrm{X}<1$, and $\sigma \mathrm{X} \geq 1$ implied that the responses were concentrated around the mean (high consensus), responses were moderately distributed, and there was no consensus on the given metric respectively. All the indicators of strategy execution had the respondents tending to strongly agree due to means of above 4.5 except in relations to national schools having effective ways of determining and ensuring LCP which the respondents on average tended to agree due mean of 4.4943 .

\section{Multiple Linear Regression of Strategy Execution}

The cumulative effect of strategy execution metrics on the academic performance was examined using multiple linear regression analysis. The positive multiple correlation coefficient $(\mathrm{R})$ indicated the cumulative effect of strategy execution is positively correlated to academic performance of national schools. There is a strong and positive correlation of 0.479 between the strategy execution and academic performance of national schools. On the other hand, the coefficient of determination (R Square) of 0.229 indicates that $22.9 \%$ of the variance in academic performance can be attributed to strategy execution in national schools.

Table 3: Model Summary of Strategy Execution

\begin{tabular}{|c|c|c|c|c|}
\hline Model & R & R Square & Adjusted R Square & Std. Error of the Estimate \\
\hline 1 & $.479^{\mathrm{a}}$ & 0.229 & 0.116 & 1.46041 \\
\hline
\end{tabular}

To examine if the multiple linear regression was a good fit for data, then the ANOVA of strategy Execution was examined. Since F $(11,75)=2.030, \mathrm{p}<0.037$ then the model was considered a good predictor of academic performance as a $\mathrm{p}$ value of 0.037 , implied only a $3.7 \%$ likelihood of a multiple linear regression model giving the wrong responses. Therefore, the multiple linear regression of strategy execution was undertaken. 
Table 4: ANOVA of Strategy Execution

\begin{tabular}{|c|c|c|c|c|c|c|}
\hline \multicolumn{2}{|c|}{ Model } & Sum of Squares & df & Mean Square & F & Sig. \\
\hline \multirow{5}{*}{1} & Regression & 47.629 & 11 & 4.33 & 2.03 & $.037^{\mathrm{b}}$ \\
\cline { 2 - 7 } & Residual & 159.959 & 75 & 2.133 & & \\
\cline { 2 - 7 } & Total & 207.588 & 86 & & & \\
\hline
\end{tabular}

The multiple linear regression equation of the strategy execution was represented as per below;

Academic Performance $=8.143+0.293 X_{1}-0.668 X_{2}-0.451 X_{3}-0.291 X_{4}-0.224 X_{5}+0.396 X_{6}-0.088 X_{7}+0.068 X_{8}+$ $0.120 \mathrm{X}_{9}+1.208 \mathrm{X}_{10^{-}} 0.130 \mathrm{X}_{11}$ The multiple linear regression equation indicates that the academic performance would be at 8.143 without the strategy execution metrics. A unit increase in effective ways in determining and ensuring our key SP's was key would lead to a 1.208 increase in academic performance and was the only item that had a significant influence on academic performance due to a $\mathrm{p}$ value of 0.002 .

Table 5 Coefficients of Strategy Execution

\begin{tabular}{|c|c|c|c|c|c|c|}
\hline & & \multicolumn{2}{|c|}{$\begin{array}{l}\text { Unstandardized } \\
\text { Coefficients }\end{array}$} & \multirow{2}{*}{$\begin{array}{c}\text { Standardized } \\
\text { Coefficients }\end{array}$} & \multirow[t]{2}{*}{$\mathrm{t}$} & \multirow[t]{2}{*}{ Sig. } \\
\hline & & B & $\begin{array}{l}\text { Std. } \\
\text { Error }\end{array}$ & & & \\
\hline & (Constant) & 8.143 & 3.628 & & 2.245 & 0.028 \\
\hline $\mathrm{X}_{1}$ & We continuously assess progress relative to these action plans & 0.293 & 0.349 & 0.092 & 0.838 & 0.405 \\
\hline $\mathrm{X}_{2}$ & $\begin{array}{l}\text { We compare our projected performance with the projected } \\
\text { performance of competitors and key benchmarks }\end{array}$ & -0.668 & 0.439 & -0.185 & $\begin{array}{c}- \\
1.521\end{array}$ & 0.133 \\
\hline $\mathrm{X}_{3}$ & $\begin{array}{l}\text { We collect and integrate information on evidence of student } \\
\text { learning }\end{array}$ & -0.451 & 0.363 & -0.145 & $\overline{-}$ & 0.218 \\
\hline $\mathrm{X}_{4}$ & $\begin{array}{l}\text { Our faculty promotion process is based on accepted principles } \\
\text { of academic performance }\end{array}$ & -0.291 & 0.401 & -0.085 & $\begin{array}{c}- \\
0.727\end{array}$ & 0.469 \\
\hline $\mathrm{X}_{5}$ & $\begin{array}{l}\text { We have effective ways in motivating faculty and staff to } \\
\text { develop and utilize their full potential }\end{array}$ & -0.224 & 0.499 & -0.052 & -0.45 & 0.654 \\
\hline $\mathrm{X}_{6}$ & We have effective ways in determining and ensuring our LCP & 0.396 & 0.361 & 0.15 & 1.097 & 0.276 \\
\hline $\mathrm{X}_{7}$ & $\begin{array}{l}\text { Our LCP address student educational and developmental needs } \\
\text { to maximize their success }\end{array}$ & -0.088 & 0.376 & -0.03 & $0 . \overline{235}$ & 0.815 \\
\hline $\mathrm{X}_{8}$ & $\begin{array}{l}\text { We incorporate inputs from students, faculty, staff and } \\
\text { stakeholders to determine key LCP requirements }\end{array}$ & 0.068 & 0.39 & 0.024 & 0.175 & 0.862 \\
\hline $\mathrm{X}_{9}$ & $\begin{array}{l}\text { We continuously improve our LCP to maximize student } \\
\text { success and improve educational programs }\end{array}$ & 0.12 & 0.369 & 0.038 & 0.326 & 0.745 \\
\hline $\mathrm{X}_{10}$ & $\begin{array}{l}\text { We have effective ways in determining and ensuring our key } \\
\text { SP's }\end{array}$ & 1.208 & 0.384 & 0.397 & 3.145 & 0.002 \\
\hline $\mathrm{X}_{11}$ & $\begin{array}{l}\text { We incorporate inputs from students, faculty, staff and } \\
\text { stakeholders to determine key SP requirements }\end{array}$ & -0.13 & 0.37 & -0.042 & -0.35 & 0.727 \\
\hline
\end{tabular}

a. Dependent Variable: Overall average score for $2015 \mathrm{KCSE}$

\section{Recommendation}

The study recommended that the national schools should emphasize the role of strategy execution with view of improving on the academic performance of their schools. This was because the strategy execution had found to have a significant influence on the academic performance. This was largely attributed to the fact that the national schools boost of little variances in terms of resources and leadership dynamics hence making strategy execution a key determinant of academic performance in national schools. In particular the school should focus on the following aspects;

(i) We have effective ways in determining and ensuring our key SP's

(ii) We have effective ways in determining and ensuring our LCP

(iii) We continuously assess progress relative to these action plans

(iv) We continuously improve our LCP to maximize student success and improve educational programs

(v) We incorporate inputs from students, faculty, staff and stakeholders to determine key LCP requirements

\section{References}

[1] Ackers, J., \& Hardman, F. (2001). Classroom interaction in Kenya Primary schools. British Association for International and Comparative Education, 31(2) 245-261.

[2] Adair, J. (2002). Effective Strategic Leadership. London: Macmillan.

[3] Advance Business Consulting . (2015, 6 29). http://www.advancebusinessconsulting.com/. Retrieved from Advance Businesss Consulting : http://www.advancebusinessconsulting.com/advance!/strategic-alignment.aspx

[4] Alchian A, D. H. (1972). Production, Information cost and economic organization. American Economic Review, 777-95.

[5] Altschuld, J. W. (1995). Assessing the effectiveness of research organizations. Evaluation Review, 197-216. Retrieved from http://dx.doi.org/10.1177/0193841X9501900205

[6] Amos T. (2007). Strategic Leadership: Key driver for strategic implementation. Management Today. 
[7] Andolsen. A.A. (2007). Strategic Alignment? ARMA International.

[8] Ansoff L. (1965). Corporate Strategy. New York: McGraw Hill.

[9] Ashraf, G. K. (2012). A Review of Models of Organization Effectiveness: A look at Cameron's Model in Higher Education. International Education Studies Vol 5, 2.

[10] Avison, D. J. (2004). Using and Validating the strategic alignment model . Journal of Strategic Information Systems 13, $223-246$.

[11] Avison.D., J. J. (2004). Using and Validating the strategic alignment model. Journal of Strategic Information Systems , 13:223-246.

[12] Avolio, B., Bass, B., \& Jung, D. (1978). Re-Examining the componenets of tranformational and transactional leadership using the multifactor leadership questionaire. Journal of Occupational and Organizational Psychology; 72, 441-462.

[13] Avolio, B., Bass, B., \& Jung, D. (1999). Re-examining the componenets of transformational and transactional leadership using the multifactor leadership questionnaire. Journal of Occupational and Organizational Psychology 72, 441-462.

[14] Bain J.S. (1968). Indurstrial Organization. New York: John Wiley.

[15] Barnett, V. (2002). Guide to Statistical Information: Sampling for surveys. The Higher Education Academy : Maths Stats\& or Network.

[16] Barney J, A. A. (2001). The Resource Based View: Origins and Implications, Handbook of Strategic management. Oxford, UK: Blackwell Publishers.

[17] Barney, J. (1991). Furm Resources and sustained competitive advantage. Journal of Management, Vol.17 No.1, 99-120.

[18] Bass B. (1985). Leadership and Perfomance beyond Expectation. New York: The Free Press.

[19] Bass B.M. (1998). Transformational Leadership: Indurstry, Military and Educational Impact . Mahwah, NJ: Erlbaum.

[20] Bass B.M. (2009). Handbook of Leadership: Theory, Research and Managerial Applications. New York: Free Press.

[21] Bass, B. (2007). Executive and Strategic Leadership. Internation Journal of Business.

[22] Beare, H. (2001). Creating the future school. London, RoutledgeFalmer.

[23] Bell, L. (2002). Strategic Planning and School Management: Full of Sound and Fury, Signifying nothing? Journal of Education Administration 40(5), 407-424.

[24] Bennet, D. (2000). The school of the future, National College for school Leadership. Nottingham, NCSL: Leadership Evidence Base.

[25] Bianco, T., \& Schermerhorn, J. (2006). Self- Regulations, Strategic Leadership and Paradox in Organization Change. Journal of Organizational Change Management 19 (4), 457-475.

[26] Blazey, M. (2009). Insights to performance excellence: An Inside look at the 2009-2010 Baldrige Award Criteria. Milwaukee, Wisconsin: ASQ Quality Press.

[27] Boal, K. \&. (2001). Strategic Leadership Research. Leadership Quarterly, 11(4), 515-549.

[28] Boal, K., \& Hooijberg, R. (2001). Strategic Leadership Research. Moving On. Leadership Quarterly, 515-549.

[29] Boisot, M. (2003). 'Preparing for turbulence. In B. Garratt, Developing Stategic Thought. London: McGraw-Hhill.

[30] Brecken, D. (2004). Leadership Vision and Strategic Direction. The Quality Management Forum, Volume 30 (1), 6-7.

[31] Bridoux, F. (n.d.). A Resource Based Approach to Perfomance and Competition: An overview of the connenction between resources and competition. Institit d' Administration et de Gestion, Universite' Catholique de Louvain. Belgium.

[32] Burns J.M. (1978). Leadership. New York: Harper and Row.

[33] Business/IT- Alignment. (2015, June 30). https://businessitalignment.wordpress.com/2010/12/22/strategic-alignment-maturitymodel-luftman/. Retrieved from Business/ IT- Alignment: https://businessitalignment.wordpress.com/2010/12/22/strategicalignment-maturity-model-luftman/

[34] Cameron, K. (1981). Domains of organization effectiveness in colleges and universities. Academy of Management Journal, 24, 2547.

[35] Cameron, K. (1981). Domains of Organizational Effectiveness in institutions of higher education. Retrieved from Academy of Management Journal 24 (1): http://dx.doi.org/10.2307/255822

[36] Cannella Jr, A. (2001, August). Upper echelons: Donald Hambrick on executives and strategy.

[37] Cannella, A., \& Monroe, M. (1997). Contrasting perspectives on strategic leaders: Toward a more realistic view of top managers. Journal of management, 23, 213-238.

[38] Carpenter, M., Geletkanycz, M., \& Sanders, W. (2004). Upper Echelons Research Revisted: Antecedents, Elements and Consequence of Top Management Team Composition. Journal of Management 30(6), 749-778.

[39] Chandler A.Jr. (1962). Strategy and Structure: Chapters in the History of American Indurstrial Enterprise. Cambridge. MA: The MIT Press.

[40] Chandler. A.D. (1962). Strategy and Structure: Chapters in the History of the American Entreprise. Cambridge, M.A: The MIT Press.

[41] Cheng, Y. (2000). Strategic Leadership for Educational Transformation in the New Millennium. Chulalongkorn Educational Review 6 (2), 15-32.

[42] Chorn, N. (1991). The "alignment" theory: Creating strategic fit. Management Decision, 20-26.

[43] Chorn. H.N. (1991). The " Alignment" Theory: Creating strategic fit. Management Decision, 20.

[44] Chrispeels, j., Burke, P., Johnson, p., \& Daly, A. (2008). Aligning mental models of district and school leadership teams for reform coherence. . Journal of Case in Educational Leadership, (11)1-10, . doi: 10.1177/1555458908324903.

[45] Ciborra, C. (1997). De Profudis? Deconstructing the concept of strategic alignment. https://www.informatik.gu.se/conference/iris20/60.html.

[46] Ciulla, J. (1998). Ethics, the heart of Leadership. Westport: CT: Quorum.

[47] Cobb, A., \& Wry, T. (2014). Resource- Dependence Theory. Oxford Bibliographies, 10.1093/OBO/9780199846740-0072.

[48] Cohen, W., \& Levinthal, D. (1990). Absorptive Capacity: A new perspective on learning and innovation. Administration Science Quarterly, 35, 128-152.

[49] Col Guillot, M. (2003). Strategic Leadership; Defining the challenge,. Air \&Space Power Journal, 65-75.

[50] Compton, S. (2008). High Reliability Leadership: Developing Executive Leaders for High reliability organizations. Faculty of School of Business of the George Washington University.

[51] Cooper, R., \& Schindler, P. (2014). Business Research Methods (12th Ed.). New York: Mc-Graw-Hill Publishers.

[52] Cyert R.M \& March J.G. (1963). A Behavioural Theory of the firm. Englewood Cliffs, NJ: Prentice- Hall.

[53] D' Souza, S. (n.d.)

[54] Dalton, T. \&. (1988). The politics of measuring public sector performance: Promoting Productivity in the public sector. Macmillan.

[55] Darmody, M., \& Smyth, E. (2016). Primary Schools Principals' Job Satisfaction and occupational stress. International journalo of icational management vol.30 Issue 1, 115-128.

[56] Davies, B. (2005). The Essentials of School Leadership,. London: Crown Press. 
[57] Davies, B. (2015, 7 2). success and sustainability : Developing the strategically- focused school. Retrieved from http://www.brentdavies.co.uk/: http://www.brentdavies.co.uk/Web\%20Articles/NCSL\%20 \%20Strategy.pdf

[58] Davies, B., \& Davies, B. (2004). Strategic Leadership. School Leadership \& Managent, 29-30.

[59] Davies, B., Davies, B., \& Ellison, L. (2015, September 9). www.brentdavies.co.uk. Retrieved from http://www.brentdavies.co.uk/Web\%20Articles/NCSL\%20 \%20Strategy.pdf: http://www.brentdavies.co.uk/Web\%20Articles/NCSL\%20 \%20Strategy.pdf

[60] Davis, R., \& Mukamal, K. (2006). Hypothesis Testing Means. Statistical Primer for Cardiovascular Research, $1078-1082$.

[61] Davs, F., \& Cobb, J. (2009). Resource Dependence Theory: Past and Future. Research in Sociology of Organizations.

[62] Day, R. (1979). How to write and publish a scientific paper. Phillladelphia: ISI press.

[63] Deeboonme, W., \& Ariratana, W. (2014). Relationship Between strategic Leadership and School Effectiveness. International Conference on Education \& Educational Psychology (pp. 982-985). Procedia - Social and Behavioral Sciences 112.

[64] Diefenbaeh, T., \& Silince, J. (2011). Formal and Infromal Hierachy in Different Types of Organization. Organizational Studies , 32(11);1515-1537.

[65] Dierendonck D.V. (2011). Servant Leadership: A review and synthesis. Journal of Instruction.

[66] Dr. Almansour, Y. (2012). The Relationship Between Leadership Styles and Motivation of Managers Concceptual framework. Journal of Arts, Science and Commerce.

[67] Draft, R. (2011). The Leadership Experience (5th Edition ed.). Cincinnati, Ohio: Engage Learning South- Western.

[68] Draft, R. (2011). The Leadership Experience (5th Edition ed.). Cincinnati, Ohio: Engage Learning South- Western.

[69] Drucker P.F. (2002). Innovation and Entrepreneurship. Oxford: Butterworth-Heinemann.

[70] D'Souza., \& Dr. Sequeira, A. (n.d.). Application of Malcolm Baldrige Quality framework to enhance pefromance in healthcare organization. https://ssrn.com/abstract=2037944.

[71] Duursema, H. (2013, March 15). Strategic Leadership. Moving beyond the Leader - Follower Dyad. Strategic Leadership. Moving beyond the Leader - Follower Dyad. Duursema Hester.

[72] Eacott, S. (2011). New Look Leaders or a New Look at Leadership? . International Journal of Educational Management (25)2, 134143.

[73] Edmonds, R. (1979). Effective schools for the urban poor. Educational Leadership 37 (1), 15-27.

[74] Ercetin, S., \& Maya, I. (2010). A Ke concept in effective school development: Strategic Leadership. 2nd Internation Symposium on sustainable development , 212-215.

[75] Essens, P. B. (2005). Military Command Team Effectiveness: Model and Instrument for Assessment and Improvement. NATO RTO technical report.

[76] Essens, P. J. (2009). Team Effectiveness in Complex Settings: Cross-Disciplinary Perspectives and Approaches. New York/ Hove: Taylor and Francis Group.

[77] Evans, R., \& Lindsay, M. (2008). Managing for Quality and Performance Excellence. Mason, OH: South- Western: Cengage Learning.

[78] Fadare, S. (2013). Resource Dependency Imstitutional and stakeholder organizational theories in France, Nigerial and India. International Journal of Management and Sustainability 2(12), 231-236.

[79] Fielder, F. (1964). A contigency Model of Leadership Effectiveness. Advances in Experimental Social Pyschology, 149-190.

[80] Finkelstein, S., \& Hambrick, D. (1996). Strategic Leasership: Top executive and their effect on organizations. Minneapolis/ St. Paul MN: West.

[81] Finkelstein, S., Hambrick, D., \& Cannella Jr, A. (2009). Strategic Leadership. Theory and Research on Executite Top Management Teams and Boards. New York: Oxford Univeristy Press.

[82] Finkelstein, S., Hambrick, D., \& Cannella Jr, A. (2009). Strategic Leadership. Theory and Research on Executives , Top Management Teams and Boards. 198 Madison Avenue, New York, New York 10016: Oxford University Press.

[83] Flick, U. (2009). An Introduction to qualitative research. Sage Publications.

[84] Foma, E. (2012). Talking of Malcolm Baldrige National Quality Award. Review of Interactive Business \& Econimic Research, 223233 .

[85] Freedman, M., \& Tregoe, B. (2003). The Art and Discipline of Strategic Leadership. New York: MCGraw- Hill.

[86] Fuchs, H. M. (2000). Strategic integration: Competing in the age of capabilities. California Management Review, Vol 42 No.3.

[87] Fuchs. H.P., M. M. (2000). Strategic Integration: Competing in the age of capabilities. California Management Review, 42(3) 118147.

[88] Fullan, M. (2004). Leadership and Sustainability : System Thinkers in Action . Thousand Oaks. C.A.: Sage Publications.

[89] Gakenia, C. (2016). Strategic Leadership alignment on Academic performance: Focus on National High schools in Kenya.

[90] Gamage, D. (2006). Proffessional Development for Leaders and Managers of self governing schools. Dordrecht: Springer.

[91] Garbarine, S., \& Holland, J. (2009). Quantitative and Qualitative Methods in Impact Evaluationa nd Measuring Results. Governance and Social Development Resource Centre.

[92] Gardner, H. (1985). The mind's new science: a history of the cognitive revolution. New York: Basic Books.

[93] Geiser, S., \& Santelices, M. (2007). Validity of High School Grades in Predicting Students Success Beyond the Freshman Year. Research \& Occasional Paper Series : CSHE. 6.07.

[94] Gernert, D. (2011). The Organisation as an obstacle to creativity. International Journal of Applied Systemic studies , 4(1): 126-135.

[95] Githua, B., \& Nyabwa, R. (2008). Effects of Advance organizer strategy during instruction on secondary school students' mathematics achievement in Kenya's Nakuru district . International journal of science and mathematics education , 6(3) $439-457$.

[96] Goddard, I. a. (1993). Managing Staff in Schools . Oxford Heinmann Educational .

[97] Goddard, R., Hoy, W., \& Hoy, A. (2000). Collective teacher efficacy: Its meaning, measure, and impact on student achievement. American Educational Research Journal. 37(2), 479-507.

[98] Goldberger, S., Keough, R., \& Almeida, C. (2000). Benchmarks for success in High School Education. Putting data to work in school to career education reform. Boston. Massachusets: LAB at Brown University.

[99] Goodson R.J, M. G. (2009). Situation Leadership Theory. A Test of Leadership Prescriptions . Group \& Organization Management, $446-461$.

[100] Government of Kenya. (2012, October 19). The Kenya National Examination Council Act .

[101] Graddy, K., \& Stevens, M. (2005). The Impact of School Resources on Students Performance: A study of private schools in the United Kingdom. ILRL Review, 435-451.

[102] Graen, G. \&. (1975). A role Making Model of Leadrship in formal Organizations: A development Approach. Kent: Ohio: Kent State University Press. 
[103] Graen, G. U.-B. (1998). Relationship- Based Approach to Leadership: Development of Leader- Member Exchange (LMX) Theoriy of Leadership of 25 Years:. Greenwich CT.: Jai Press.

[104] Graen, G., \& Scandura, T. (1987). Toward a psychlogy of dyadic organizing. Research in Organizational Behaviour: 9, $175-208$.

[105] Granite State Quality Council. (n.d.). The Malcolm Baldrige Criteria for Performance Excellence. Retrieved from file://C:/Users/user/Downloads/The\%20Malcolm\%20Baldrige\%20Criteria\%20for\%20Performance\%20Excellence\%20200910.pdf

[106] Gratton, L. (2000). Living Strategy: Putting people at the heart of cororate purpose. London: Financial Times Prentice Hall.

[107] Gratton, L. (2000). Living Strategy: Putting People at the Heart of Corporate Purpose. London: Financial Times Prentice Hall.

[108] Greenleaf R.K. (1977). Servant Leadership. Mahwah: NJ: Paulist Press.

[109] Greenwald, R., Hedges, L., \& Laine, R. (1996). The Effect of School Resources on Student Achievement. Review of Educational Research, , 361-396.

[110] Grix, J. (2010). The foundations of reseach. London: Palgave Macmillan.

[111] Guba, E., \& Lincoln, Y. (1996). Competing Paradigms in Qualitative Reseach. In Denzin \& Lincoln ( Eds.), Handbook of Qualitative Research . USA : Sage Publishers.

[112] Guillot, W. (2003). Strategic Leadership: Defining the challenge. Air \& Space. Power Journal- Winter.

[113] Gupta, J. N. (2009). The Handbook of Research On Entreprise Systems. Hershey, Newyork: Information Science Reference.

[114] Hagen, A., Hassan, M., \& Amin, S. (1998). Criticial Strategic Leadership Components: an empirical investigagtion . SAM Advanced Management Journal, 63(3), 39-44.

[115] Hallinger, p., \& Heck, R. (1996). Reassessing the principal's role in school effectiveness: A review of empirical research 19801995. Educational Administration, Quarterly 32 (1), 5-44.

[116] Hambrick, D. (n.d.). u.

[117] Hambrick, D., \& Finkelstein, S. (1987). Managerial Discretion : A bridge between popular views of organizations. In L. Cummings, \& B. (. Straw, Research In Organizatonal Behaviour ( Vol 9) (pp. 396-406). Greenwich. CT: JAI Press.

[118] Hambrick, D., \& Mason, P. (1984). Upper Echelopns: Donald Hambrick on executive and strategy. Academy of Management Review, 9, 193-206.

[119] Hambrick, D., \& Pettigrew, A. (2001). Upper Echelons: Donald Hambrick on Executives and Strategy. Academy of Management Executives, 15 (3): , 36-44.

[120] Hammonds, K. (2001). Michael Porter's big Ideas. Fast Company, 44, 150-156.

[121] Handerson J.C. (1990). Plugging into strategic partnerships: The critical IS connection. . MIT Sloan Management Review 31 (3), 12-18.

[122] Hannah, S. A. (2008). Leadership efficacy: review and future directions. The Leadership Quarterly, (19), 669-692.

[123] Hatch, M. (1997). Organization Theory: Modern, Symbolic and Postmodern perspectives. Oxford: Oxford University Press.

[124] Hayat, K., Hussain, S., \& Sardar, S. (n.d.). Summary and Analysis Stephen R. Covey's the 8th Habit: From effectiveness to Greatness. Abasyn Journal of Social Sciences. Vol:8 Issue 1, 184-197.

[125] Head Quarters Department of the Army . (2015, June 30). FM 6-22 Leadership Development. Washington, DC, Washington DC, USA.

[126] Henderson, J., \& Venkatramen, N. (1992). Strategic Alignment:A model for organizational Transformational.

[127] Henn, M., Weinstein, M., \& Foard, N. (2006). A Short Introduction to social research. London: Sage.

[128] Hersey, P. B. (1969). Management of Organizational Behaviour: Utilizing Human Behaviour. Englewood Cliff: NJ: Prentice- Hall.

[129] Hitt, L., Wu, D., \& Zhou, X. (2002). Investment in Enterprise resource planning: Business Impact and productivity measures. Journal of Management Information Systems, 19, 71-98.

[130] Hitt, M., Ireland, R., \& Hoskisson, R. (2007). Strategic Management: Competitiveness and globalization (7th ed.). Mason, Ohio: Thomson/ South Western.

[131] Hitt, M., Ireland, R., \& Hoskisson, R. (2011). Strategic Management Competitiveness \& Globalization. Mason, OH: SOUTHWESTERN CENTAGE Learning.

[132] Hoffer, C., \& Schendel, D. (1978). Strategy formulation: Analytical concepts. St. Paul MN: West.

[133] Hoskisson, R., Hitt, M., \& Ireland, R. (2004). Strategic Leadership. In Competing for Advantage. South Western: Thompson.

[134] House R.J \& Aditya R. (1997). The Social Scientific study of Leadership: Quo Vadis? Journal of Management, 23. 409-474.

[135] House, R., \& Aditya, R. .. (1997). The Social Scientific Study of Leadership: Quo Vadis? Journal Of Management, 23, $409-474$.

[136] House, R., \& Mitchell, T. (1974). Path-Goal Theory of Leadership. Journal of Contemporary Business, 81-97.

[137] Howell, j., \& Dorfman, p. K. (1986). Moderator Variables in Leadership Research. Academy of Management Review, 11, 88-102.

[138] Hoy, W., \& Miskey, C. (2008). Educational Administration: Theory, research and practise, 8th edition . Boston: McGraw-Hill.

[139] Hrebiniak, L. (2005). Making Strategy Work- Leading effective execution and change. Wharton School Publishing .

[140] Hunt J. G. Dodge G.E. (1997). Leadership Complexity and development of Leaderplex Model. Journal of Management , 23, 375408.

[141] Hunt J.G. (1991). Leadership A new synthesis. Newsbury Park, CA: Sage,.

[142] Hunt J.G. (1999). Transofmration/ Charismatic Leadership's Transformational of the field. An Historical Essay . Leadership Quarterly, 129-144.

[143] Improvement, U. D. (1997). Public and Private Schools: How do they differ. 1-39.

[144] Ireland, R. H. (2005). Achieving and Maintaining strategic competitiveness in the 21st Century: The role of Strategic Leadership. Account of management executive, Vol 19, No. 4.

[145] Jaggi, S. (n.d.). Descriptive Statistics and Explatory Data Analysis.

[146] Johnson G., S. K. (2009). "Fundamentals of Strategy. Pearson Education Limited.

[147] Judge, T., \& Piccolo, R. (2004). Transformation \& Transactional Leadership: A Meta- Analytic test of relative valility. . Journal of Applied Psychology. 89(5), 755-768.

[148] Junarso, T. (2009). Leadership Greatness. Best practises to become a great leader. New York: iUniverste.

[149] Kaplan R.S \& Norton D.P. (2006). Alignment: Using the balance scoreccard to create corporate synergies. Boston: Harvard Business School.

[150] Kaplan, L., Owings, W., \& Nunnery, J. (n.d.). Principal quality: A Virginia study connecting interstate school leaders licencesure consortium standards with student achievement. NAASP Bullentin, 89 (643), 28-44.

[151] Kaplan, R., \& Norton, D. (2001). On balance. CFO, 17, 73-78.

[152] Kaplan, R., \& Norton, P. (2005). The Office of Strategy Management. Havard Business Review, October 2005 Issue.

[153] Keller, R. (2006). Transformational Leadership, initiating structure and substituties for leadership: A longitudinal study of research and development project team performance. Journal of Applied Psychology. 91(1), 202-210. 
[154] Kerr, S. J. (1978). Substitutes for Leadership: Their meaning and measurement. Organizational Behaviour and Human Performance , 375-403.

[155] Kerr, S., \& Jemier, J. (1978). Subsitutes for leadership: Their meaning and measurements. Organization Behaviour and Human Performances. 22, 375-403.

[156] Khadem R. (2008). Alignment and follow-up: steps to strategy execution. Journal of Business Strategy 29(6), 29-35.

[157] Kilmoski, R., \& Zaccaro, J. (2001). The Nature of Organizational Leadership: Understanding the Performance Imperatives Confronting today's leaders . Society for Indurstrial and Organizational Psychology.

[158] Kitonga, D., Bichanga, W., \& Muema, B. (2016). strategic leadership and organization performance in Not for Profit organizations in Nairobi County in Kenya. International Journal of Scientific and Technology Research, Vol.5, 17-27.

[159] Kleijnen, J. D. (2009). Organisational values in higher education: Perceptions and preferences of staff. Quality in Higher Education, 15 (3), 233-249.

[160] Kleijnen, J., Dolmans, D., Muijtjens, A., Willems, J., \& Van Hout, H. (2009). Organisational values in higher education: Perceptions and preferences of staff. Quality in Higher Education, 15 (3), 233-249.

[161] Koskei, R., \& Katwalo, A. D. (2013). Analysis of the Influence of Strategic Leadership capability on performance of research insitutions in Kenya. International Journal of Science and Research (IJSR), 1830-1837.

[162] Kruger, M., Witziers, B., \& Sleegers, P. (2007). The impact of school leadership on school level factors: Validation of causal model . School Effectiveness and School Improvement 18 (1), 1-20 doi: 10.1080/09243450600797638.

[163] Kuhn, T. (1962). The structure of scientific revolutions. Chicago IL.: Unversity of Chicago Press, 1962.

[164] Kuznets, N. (n.d.). Using benchmarking measurement to improve performance over time. AAAHC quality improvement strandards.

[165] Labovitz G.H \& Rosansky V. (1997). The Power of Alignment:how great companies stay centred and accomplish extraordinary things. New York: Wiley.

[166] Labovitz, G. (2004). The Power of alignment: how the right tools enhance organisational focus. Business Performance Management , 30-35.

[167] Labovitz, G. a. (1997). The power of alignment: how great companies stay centred and accomplish extraordinary things. New York: Wiley.

[168] Labovitz, G., \& Rosansky, V. (1997). The power of alignment: How great companies centrered and accomplished extraordinary things. New York. NY: John Wiley and Sons.

[169] Lear, L. (2012). The relationship between strategic leadership and strategic alignment in high-performing companies in South Africa.

[170] Lear. W.L. (2012). The relationship between strategic leadership and strategic alignment in high-performing companies in South Africa.

[171] Leithwoo, K., Day, C., Sammons, P., Harris, A., \& Hopkins, D. (2006). Successful School Leadership. What is it and How it Influences Pupil Learning. Nottingham: University of Nottingham.

[172] Leithwood, K., \& Mascall, B. (2008). Collective Leadership effects on student achievement . Educational Administration Quartlerly, 44 (529), 1-34; doi: 10.1177/0013161X08321221.

[173] Leithwood, K., Seashore, K., Anderson, S., \& Wahlstrom, K. (2004). How Leadership Influences student learning. Minnesota: The Wallace Foundation.

[174] Lezotte, L. (2001). Revolutionary and evolutionary: The effective schools movement. Okemos, MI: Effective Schools Products, Ltd.

[175] LI, Z., Gupta, B., Loon, M., \& Casimir, G. (2016). Combinnative aspects of leadership style and emotional intelligence. Leadership and Organization Development Journal Vol. 27 Iss:1 , 107-125.

[176] Liu, B., \& Fu, Z. (2011). Relationship between strategic orientation and organizational performance in Born Global: A Critical Reivew. International Journal of Business and Management, 109-115.

[177] Lord R.G, M. K. (1984). A Test of Leadership Categorization theory: Internal Structure, Information Processing and Leaderhip Perception. Organizational Behavior and Human Performance, 34, 343-378.

[178] Lord, R., \& Moher, K. (1991). Leaderhip and information processing. Boston: Unwin Hyman.

[179] LTC. Tirtan, C. (2011). Organization Culture. The 6th International Scientific Conference.

[180] Luftman, J. (2000). Assesing Business- IT Alignment Maturity. Commnucations of Assosiation for Information Systems, Article 14.

[181] Luftman, J. L. (1996). Transforming the entreprise: The Alignment in Practise. New York: Oxford Press

[182] Luftman, J. P. (1999). Enablers and Inhibitors of Business- IT Aligment. Communications of the Association for Information Systems, Volume 11.

[183] Lundholm, M., Simsek, Z., Ling, y., \& Veiga, j. (2006). Ambidexterity and Performance in Small - to medium sized firms: The pivotal role of top management team behavioural integration. Journal of Management, 32(5);646-672.

[184] Lundholm, S., Rennstam, J., \& Alvesson, M. (2012). Understanding Hierachy in Contemporary Work. Emarald Group Publising.

[185] Lydia, L., \& Nasongo, J. (2009). Role of the Lead teacher in academic achievement in secondary schools in Vihiga District, Kenya Current Research. Journal of Social Sciences 1(3), 84-92.

[186] Macedo, I., \& Pinho, C. (2006). The relationship between resource dependence and market orientation: The specific case of non-profit organisations. European Journal of Marketing, Vol. 40 Iss: 5/6, pp.533 - 553.

[187] Mackey A. (2008). The Effect of CEO's on organizational Performance. Strategic Management Journal , $1357-1367$.

[188] Makgone, S. (2012, November). An evaluation of strategic leadership in selected schools and its contribution to academic perfomance.

[189] Martimore, P. (1998). The Road to Improvement: Reflections on School Effectiveness. Swets \& Zeitlinger Publishers.

[190] Maru, P. (2013). INFLUENCE OF PRINCIPALS 'LEADERSHIP STYLES ON STUDENTS' PERFORMANCE AT KENYA CERTIFICATE . Nairobi.

[191] Mason E. ( 1939). Price and Production Policies of Large Scale Enterprises. Amaerican Economic Review, 61-74.

[192] Mathe, S., \& Dr. Kiiru, G. (2016). Effects of Strategic Leadership on Perfomance of MFI's Kenya. International Journal Of Advancement In Engineering Technology, Management and Applied Science. Vol 03- Issue 11, 114-119.

[193] McDaniel, C., \& Gates, R. (2015). Marketing Research, 10th Ed. Wiley E-Text.

[194] McGrath, G., \& MacMillan, I. (2000). Entrepreneurial Mindset: Strategies for Continously Creating Opportunity in an Age of Uncertainity. Havard Business School Press Books.

[195] Mehra, A., Smith, B., Dixon, A., \& Robertson, B. (2006). Distributed leadership in teams: The network of leadership perceptions and team performance. The Leadership Quarterly, 232-245.

[196] Meindl J.R, S. E. (1985). The Roman of Leadership. Administrative Science Quarterly, 78-102. 
[197] Meindl, J. (1993). Reinventing Leadeship: A Radical social psychological apporach in J.K. Murningham (Ed). Englewood , NJ: Prentice Hall.

[198] Mertens, D. (2005). Research Methods in education and psychology: Integrating diversity with quantitative and qualitative approaches. Thousand Oaks: Sage.

[199] Ministry of Education. (1980). Education Act. Chapter 211. Nairobi: Government Printer .

[200] Montgomery, C. (1993). Putting Leadership back into strategy. Havard Business Review. May/ June: 76.

[201] Morgan, G. (1997). Images of Organizations. Thousand Oaks. CA: Sage Publications.

[202] Munir, F., \& Khalil, U. K. (2016). Secondary School Teachers' Perceptions of their Principal's Leadership Behaviours and their academic performance at Secondary School Level. Bulletin of Education and Research, 41-55.

[203] Musungu, L., \& Nasongo, J. (2008). The head-teacher's instructional role in academic achievement in secondary schools in Vihiga district Kenya. Educational Research and Review.

[204] Mutia, P. (2015). Strategic Leadership influence on church growth in Kenya. Retrieved from http://erepo.usiu.ac.ke/: http://erepo.usiu.ac.ke/bitstream/handle/11732/2641/PETER\%20M.\%20MUTIA\%20DBA\%20Thesis\%202016.pdf?sequence=1\&is Allowed=y

[205] Mwamuye, K. (2012). The Role of Leadership in Performance of Primary Schools in Kenya: A Case of Mombasa District. International Journal of Business of Commerce, 21-36.

[206] Narayanan, V., \& Zane, L. (2009). Inventing a future for strategic leadership phenomenal variety and epistemic opportunities. Journal of Strategy and Management, 2(4), 380-404.

[207] National Comprehensive centre for Teacher Quality. (2010). Evaluating school principals

[208] Naver, J., \& Slater, S. (1990). The effect of a market orientation on business profitability. Journal of marketing, 54(4), 20-35.

[209] Nganga, U. (2013). Strategic leadership and performance of manufacturing firms in Kenya.

[210] Nthenya, S. $(2015,101)$. Challenges faced by secondary school headteachers in leadership and management of human resources- in Nzaui district Makueni county- Kenya. Nairobi.

[211] Nthini, E. (2013). Effects of strategic leadership on the performance of commercial and financial state corporations. Retrieved from chss.uonbi.ac.ke/sites: http://chss.uonbi.ac.ke/sites/default/files/chss/Evelyn\%20Katee\%20Nthini-\%20MBA\%20Project_1.pdf

[212] Nueman, W. (2006). Social Research Methods: Qualitative and Quantiative Approaches, 6th Edition . Boston: Pearson Education.

[213] Nyamboga, O.T.,; Gwiyo, S.J.,; Dr Njuguna, F.W., ; Dr.Waweru S.N.,; Nyamweya, B.O.,; Gongera, P.G.,. (2014). Journal of Education and Practise, Vol. 5. No 22.

$\begin{array}{lllll}\text { [214] Nyongesa, } & \text { P. } & \text { (2014). } & \text { www.uonbi.ac.ke. } & \text { Retrieved }\end{array}$ http://erepository.uonbi.ac.ke/bitstream/handle/11295/77724/Lukingi_Head\%20teacher\%E2\%80\%99s\%20leadership\%20style\%20o n\%20school\%20academic\%20performance\%20in\%20Kenyan\%20secondary\%20schools.pdf?sequence=1.

[215] Obunga, C., Marangu, W., \& Masungo, T. (2015). Strategic Leadership and Performance of Saving and Credit Co-operative societies in Kakamega County, Kenya. European Journal of Business and Management, Vol 7, No.13, 65-75.

[216] Odumeru, J., \& Ifeanyi, G. (2013). Transformational Vs. Transactional Leadership Theories: Evidence in Literature. Internation Review of Managaement and Business Research Vol.2 Issue.2, 355-361.

[217] Okode, G. (2013). Influence of Secondnary Schools Strategic Plannihng on Students Academic Performance in Rachuonyo North District, Kenya. Retrieved from http://erepository.uonbi.ac.ke/: http://erepository.uonbi.ac.ke/bitstream/handle/11295/55797/ABSTRACT.pdf?sequence=3

[218] Orndoff, K. (2002). Developing strategic competencies: a starting point. The information management journal. July- August, 57-52.

[219] Pedersen, K. (2008). Cracking the code of Strategy Execution. Copenhagen Business School.

[220] Porter, M. (1996). What is strategy? Harvard Business Review, 61-78.

[221] Prahalad, C., \& Hamel, G. (1990). The core competencies of the corporation. Harvard Business Review,, 68: 79-93.

[222] Prof.Scheerens, J. (2013). What is effective schooling. International Baccalaureate Organization.

[223] Pugh, D., \& Hickson, D. (1993). Great writers on organizations: The omnibus edition. Brookfield, VT: Dartmouth Publishing.

[224] Quinn R. E. (1988). Beyond Rational Management. San Francisco, C.A: Jossey- Bass.

[225] Quong T. \& Walker A. (2010). Seven Principles of Strategic Leadership. Academia Edu, Volume 38.

[226] Quong, T., \& Walker, A. (2010). Seven Principles of Strategic Leadership. International Studies in Educational Administration, Vol $38,22-35$.

[227] Rafferty A.E, G. M. (2004). Dimensions of Transformational Leadership: Conceptual and Empirical Extensions. The Leadership Quarterly, 15, 329-354.

[228] Ramchandra, R., Nagamani, M., \& Sripirabaa, B. (2009). International Conference on Managing Educatiaon for Business and Commerce in a Globalised World. Strategies for Excellence. New Delhi. Mumbai. Kolkata. Chennai. Nagpur. Ahmedabad. Bangalore. Hyderabad. Lucknow: Allied Publishers Private Ltd.

[229] Rautiola, J. (2009). Effects of leadership styles and student academic achievement. School Leadership and Academic Achievement .

[230] Rautiola, J. (2009, July 19). EFFECTS OF LEADERSHIP STYLES AND STUDENT ACADEMIC ACHIEVEMENT. Retrieved from www.nmu.edu: https://www.nmu.edu/sites/DrupalEducation/files/UserFiles/Files/PreDrupal/SiteSections/Students/GradPapers/Projects/Rautiola_James_MP.pdf

[231] Robbins, S. P. (2003). Essentials of organizational behavior. Prentice Hall.

[232] Rojas, R. (2000). Review of models for measuring organizational effectivness among for profit and non profit organizations. NonProfit management and Leadership 11(1), 97-104.

[233] Rose, J., \& Gray, P. (2006). School Leadership and Student Achievement: The mediating effects of teacher beliefs. Canadian Journal of Education 29 (3), 798-822.

[234] Rowe. (2001). Creating wealth In Organizations: The Role fo Strategic leadership. The Academy of Management Executives 15 (1), $81-95$.

[235] Rowe, G. (2001). Creating Wealth in Organizations: The role of strategic Leadership. The Academy of Management Executive, 8194.

[236] Rowe, W. (2001). Creating wealth in organizations: The role of strategic leadership. Academy of Management Executive 15 (1), 81-95.

[237] Rowe.G. \& Nejad.M.H. (2009). Strategic leadership: shrt-term stablity and long-term viability. Ivey Business Journal, 73 (5); 6-11.

[238] Sanders, T. J., \& Davey, K. (2011). Out of the Leadership theory joungle: a proposed meta- model of strategic leadership.

[239] Sanders, T. L. (1998). Strategic thinking and new science. New York: Free Press.

[240] Schermerhorn, J. R. (2004). Core concepts of organizational behavior. John Wiley \& Sons Inc. .

[241] Schreerens, J. (1999). School Effectiveness in Developed and Developing countries; a review of the research evidence. Netherlands: World Bank. Retrieved from web.worldbank.org/archive/website00237/.../JAAP699.DOC. 
[242] Seifu, G. (2016). Assessment of the implementation of continuous assessment: the. European Journal of Science and Mathematics Education, 534-544.

[243] Selznick P. (1984). Leadership in Administration: A sociological interpretation. Berkeley: Berkely University of California Press .

[244] Senge, P. (1999). The fifth discipline: he art and practice of the leearning organization. New York: Currency Doubleday.

[245] Serfontien, K., \& Hough, J. (2011). Nature of the Relatioship Between Strategic Leadership Operational Strategy and Organizational Performance. Sajems Ns 14, 393-405.

[246] Slawinski, N. (2007). Strategic Leadership. 297.

[247] Smaczny, T. (2001). Is an alignment between Business and IT the Appropriate paradigm to manage IT in Today's organization ? . Management decision 39 (10), 797-802.

[248] Stalk, G., Evans, P., \& Schulman, L. (1992). Competing on capabilities: the new rules of corporate strategy. Harvard Business Review, 70, 57-69.

[249] Statistics Canada. (2010). Survey Methods and Practises. Ottawa: Minister of Indurstry.

[250] Steers, R. (1975). Problems in the Measurement of Organizational Effectiveness. Administrative Science Quarterly , 546.

[251] Steyn, H., \& Wolhuter, C. (2010). Creating Sustainable Learning Environment of Schools by Strategic Planning: The Experience of Engagement by Comparative Education Team at University . South African Journal of Higher Education (24)3, 56-70.

[252] Steyn, H., Wolhunter, C., \& . (2010). Creating Sustainable Learning Environment of Schools by means of strategic planning: The experience of Engagement by Comparative Educatio Team at University,. South African Journal of Higher Education 24 (3), 56-70.

[253] Stogdil, 1. R. (1957). Leader Behaviour: Its Description and Measurement. Ohio: Bureau of Business Research. Ohio State University.

[254] Stone, G., \& Patterson, K. (2005). The history of leadership focus. Servant Leadership Research Roundtable.

[255] suskavcevic, M., \& Blake, S. (1999). Educational Leadership and Student Achievement: An Examination of the third international Maths and Science study. Internation Research Conference, Lefcosia, Cyprus, May 11-13, 2004.

[256] Tanner, S., \& Bailey, M. (2014). From ISO 9001 to World-Class Performance. London: Berforts Group.

[257] Teece, D., Pisano, G., \& Shuen, A. (1997). Dynamic Capabilities \& Strategic Management . Strategic Management Journal 18(7), 509-533.

[258] TerreBlanche, M., \& Durrheim, K. (1999). Research in Practise. Cape Town: University of Cape Town Press.

[259] The strategic position: strategic capabilities. $\quad(2007, \quad 10 \quad 15)$ Retrieved catalogue.pearsoned.co.uk/assets/hip/images/catalog/...ECS8_C03.pdf: http://catalogue.pearsoned.co.uk/assets/hip/images/catalog/uploads/ECS8_C03.pdf

[260] Tihany L, E. A. (2000). Composition of Top Management Team and Internation Diversification. Journal of Management, 26, 11571177 .

[261] Turner, A. (2003). Sampling Frames and Master Samples. United Nations Secretariat: Statistics Division.

[262] Ulrich, D., \& Barney, J. (1984). Perspectives in organizations: Resource dependency efficiency and population. Academy of Management Review, 9., 471-481.

[263] UNESCO. (2010). Strategic Planning as Effective Tool of Strategic Management in Public Sector Organizations: Evidence from Public Tranist Organizatons . Administration and Society (1), 87-123.

[264] Vera, S., \& Crossan, M. (2004). Strategic Leadership and Organizational Learning. Academy of Management Reviews, Vol.29. No.2, 222-240.

[265] Verweire, K. B. (2005). Integrated Performance Management . London: SAGE.

[266] Volberda, H., Morgan, R., Reinmoeller, P., Hitt, M., Ireland, R., \& Hoskisson, R. (2011). Strategic Management Competitiveness and Globalization, . Hampshire: United Kingdom: Concepts and Cases, 9th Edition.

[267] Vroom V.H. (1964). Work and Motivation. San Francisco; CA: Jossey- Bass.

[268] Wanjala, C. (2014). Strategic Planning in Schools in Kenya; Possibilities and Challenges. ISEA. Volume 47 Number1, 2014.

[269] Wanjala, C., \& Rarieya, F. (2014). Strategic Planning in Schools in Kenya:Possiblities and Challenges. Academic Edu.

[270] Warnecke, R. (2005). Sampling Frames. Encyclopedia of Biostatistics.7. DOI: 10.1002/0470011815.b2a16063.

[271] Wasserman, N. (2014). The Founder's Resource- Dependence Challenge. Harvard Business School.

[272] Waters, J., Marzano, R., \& McNulty, B. (2004). Leadership that sparks learning. Educational Leadership 61(7), 48-51.

[273] Weaver, K., \& Olson, J. (2006). Understanding paradigms used for nursing research. Journal of Advance Nursing, DOI: 10.1111/j.1365-2648.2006.03740.x.

[274] Weill, P. \&. (1998). Leveraging the New Infrastructure. Harvard Business School Press.

[275] Weiss, W. B. (2006). Transforming Military Leaders

[276] Wernerfelt, B. (1984). Reource-Based View. Strategic Management Journal, 171-80.

[277] Winston, E., \& Patterson, K. (2006). An integrative definition of leadership. Internation Journal of leadership studies.

[278] Wit, B., \& Meyer, R. (2010). STRATEGY. Process, content and context. Cheriton House, North Way, Andover, Hampshire SP10 5BE. United Kingdom: South- Western. Cencage Learning.

[279] Wong, L., Gerras, S., Kidd, W., Pricone, R., \& Swengros, R. (2003). Strategic Leadership Competencies.

[280] www.nist.gov/baldrige. (2013-2014). Retrieved from Baldrige Performance Excellence Program.

[281] Yukl G. (2002). Leadership in Organizations. Saddle- River: NJ: Prentile- Hall.

[282] Yukl, G. (1999). An evaluation essay on current conceptual weaknesses in transformational and charismatic leadership. The Leadership Quarterly, 285-305.

[283] Zaccaro, S. (2003). E- Leadership and Challenges of Leading E- Teams: Minimizing the bad and Maximizing the Good. Organanization Dynamics, 377-387.

[284] Zhu, W., Chew, I., \& Spangler, W. (2005). CEO transformational leadership and organizational outcomes:The mediating role of human-capital-enhancing human resource management. Leadership Quarterly 16(1), 39-52.

[285] Zikmunnd, W., Babin, B., Carr, L., \& Griffin, M. (2013). Business Research Methods. Mason , OH: South- Western. Cengage Learning. 